not lead to the production from the altered tissue cells of what would be generally admitted to be independent living organisms; and certainly the process cannot possibly be cited as an illustration of "the origin of life." Life was already existent in the tissue cells - their mode of life has only been changed; a process allied to heterogenesis has occurred.

I cannot, therefore, agree with Sir Henry Butlin when he goes on to say: "The host in which it dwells has fashioned it out of its own tissues, and, to borrow the figurative language of Scripture, the Creator has breathed into it the breath of life. ...... After ages of past and present civilisation, during which searchers and philosophers have sought to explain the origin and nature of life, we have come no farther than this."

The true origin of cancer, as I maintain, is related to heterogenesis, and not, as he thinks, to the still more mys terious problem to which he refers; nor can it fairly be said that in regard to the solution of this problem we have come no further than the establishment of this particular instance of heterogenesis.

Probably Sir Henry Butlin has never studied my little book entitled "The Origin of Life" (1911), where experiments are described in which multitudes of independent living organisms have been taken from tubes (previously sealed hermetically) containing certain saline fluids which had some months before been heated for periods varying from 5-20 minutes to temperatures ranging from $125-145^{\circ} \mathrm{C}$., while most of the organisms that had been produced within the tubes were such (torulæ and micrococci) as are known to be killed by exposure in fluids to $60-70^{\circ} \mathrm{C}$. for a few minutes. Such experiments surely take us much further towards the solution of "the great enigma" than does any mere proof of the heterogenetic origin of cancer cellshowever much they may be shown to be related to many of the protozoa.

I am, Sir, yours faithfully, H. Charlton bastian.

The Athenæum, s.W., Dec. 2nd, 1911.

\section{THE UNICELLULA CANCRI.}

To the Editor of THE LANCET.

SIn,-Sir Henry Butlin has stated the case for the unicellula cancri with his wonted lucidity and force, but venture to question whether he has reduced his thesis to the simplest terms. Is it not a fact that, viewed from the broad biological standpoint, all the cells of multicellular organisms (metazoa) are protozoa? Are not the aggregated cells constituting the metazoa and the segregated cells known as the protozoa all separate, individual animal organisms bathed in a fluid from which they extract their oxygen and nutriment, and to which they yield their excreta? In the higher metazoa some of these cells-e.g., muscle cells and neurons-are highly specialised and have lost the power of multiplying : such never give rise to cancer cells. Otherse.g., epithelial, endothelial, and connective tissue cells-are less specialised and retain the power of multiplying: there is no doubt that it is from these that the cancer cells are derived. Do we, however, by labelling such cells " parasitic protozoa," " unicellulæ cancri," advance our knowledge?

The cancer cells are manifestly cells which have thrown of their allegiance to the body politic and become rebels. The whole problem of cancer is summed up in the question, What is the cause of this act of rebellion

I am, Sir, yours faithfully,

Wimpole-street, W., Dec. 3rd, $1911 . \quad$ HARRY CAMPBELL.

\section{PHYSICAL TRAINING IN SECONDARY SCHOOLS.}

To the Editor of THE LANCET.

SIR, - I have read with great interest the article on "Physical Training in Secondary Schools," which appeared in your issue of Oct. 21st (p. 1150), and heartily endorse the contents thereof, especially the remark that "the gymnastic teacher should possess expert training and should be a member of the school staff." THE LANCET also points out that, whereas there are many expert lady teachers of Swedish gymnastics, there is a great dearth of expert male instructors. The reason for this state of affairs is that several excellent institutions exist for the teaching of lady students of gym. nastics, but that there have hitherto been no similar institutions for male students. An inquiry into the arrangements for teaching gymnastics in other countries reveals the striking fact that the subject has been made a university one in a considerable number, and that special schools, controlled by the State, exist for the teaching of it. Let me quote some examples:-

Sweden.-The Royal Central Gymnastic Institute, founded at Stockholm in 1813, provides a course of study of three years' duration, which includes all the branches of Ling's system. The first two years are devoted to educational and military gymnastics, and the course of instruction includes anatomy (dissections are compalsory), applied anatomy of gymnastics, and physiology. The third year is devoted to medical gymnastics, some theoretical work in which has already been gone through in the second year. Examinations are held at regular intervals, and after passing the final examination the title of gymnastic director is conferred upon the candidate. The institute is under medical supervision, and the chief teachers have the title of Professor and rank as such.

Belgium.-The Institute Supérieur d'Éducation Physique attached to the University of Ghent was duly opened in 1908. After three years' training in pbysical education the candidate receives the title of Licentiate in the Science of Physical Education. Later on, after further examination and the presentation of a thesis which the licentiate must defend, he may ubtain the title of Doctorate in the Science of Physical Education. The syllabus of the course seems to show that it is very complete.

In Austria there are State institutions in Vienna, Prague, and Gratz. Similar institutions are to be found also in Bavaria, Prussia, Saxony, and Norway. I see, also, that physical education is included in the curriculum of the University of Wisconsin. In Denmark the subject of $\mathrm{gym}=$ nastics has quite recently been made an optional subject for the degree of B.A., B.Sc., and diplomé as school teacher.

In England gymnastics is, I regret to say, neither a university subject nor one which interests the medical profession as a whole. Indeed, I have no hesitation in saying that a medical man who opened a gymnasium for educational gymnastics would be shunned by his colleagues. Even the medical supervision of school gymnastics is almost an unknown factor in this country. This is not as it should be, and I consider that THE LANCET exactly states the case when it says that there should be a close coöperation between the medical officer and the gymnasium instructor. The fact cannot be denied that physical education largely enters into the subjects of hygiene and prevention of disease, and that overdoing or misuse of it leads to pathological conditions, especially in school children. Under these circumstances I feel that many will agree with me when I suggest that physical education be made one of the subjects of the ordinary medical curriculum.

The state of affairs at present is that gymnastic classes are held in the vast majority of the schools by people who are not competent to take them, and as matters stand now children with adenoids, with spinal curvatures, with weak chests are all performing the same gymnastic exercises together with healthy children, and they are doing so under the direction and control of a teacher who is incapable of judging whether he is doing good or harm thereby. Outside schools we have an equally deplorable state of affairs in many directions. The advertising quack who does a large and flourishing trade in so-called scientific gymnastics, with or without some special apparatus, and who boasts of selfarrogated invention and discovery, need only be mentioned.

The only way to improve matters is for the medical pro fession to take them into their own hands, for until they do so no change can be effected, and I sincerely hope this will be done ere long. In connexion with this, however, I should like to point out that an institute for teaching educational gymnastics will be open in this city in Marylebone in the immediate future. The object of the institute is to give thorough instruction, theoretical and practical, in the science of physical edncation on the basis of the Swedish system of gymnastics. The course of training will follow as closely as possible the lines upon which the Royal Central Institute at Stockholm is working, with such modifications as occasion requires. The syllabus of the Board of Education will be thoronghly studied and the requirements of the Board will be 
met. Anatomy, physiology, theory of movement, hygiene, \&c., will be included in the syllabus. The practice of gymnastics will be learnt and taught by students, for which latter purpose classes of school children will be available. 'The course of training will be of two years' duration, but is so arranged that the first year will form a complete course by itself, fitting the student for posts in elementary schools. The second year's course will enable the graduates to take full charge of any school of whatever standing. A special feature of the institute will be that facilities will be afforded to medical men to gain information and to critically observe the work done.-I am, Sir, yours faithfully,

Edgar F. Cyrrax, M.D. Edin.

Craven-hill, W., Dec. 2nd, 1911.

\section{THE PRESCRIPTION OF TUBERCULIN.}

To the Editor of THE LANCET.

SrR,-In the courteous review of our work "Diseases of the Lungs," which appeared in THE LANCET of Nov. 25th, the important question is raised as to whether tuberculin should be prescribed in fractions of a cubic centimetre or milligramme. Before advocating the prescription and dispensing of the remedy in cubic centimetres we went carefully into the matter with Messrs. Squire and came to the conclusion that for accuracy and facility of dispensing the volumetric measurements were the best.

We beg to submit the following memorandum which we have receivea from Mr. P. W. Squire on the subject. We are, Sir, yours faithfully,

\section{R. DOUGLAS POWELL. \\ London, Dec. 4th, 1911. \\ P. HoRton-Simth HaRtley.}

[ENCLOSURE.]

The writer of the review in THE JANCET of Nov. 25th, 1911, is evidently under the impression that he would be obtaining the same anount of solid substance whether he ordered a fraction of I gramme or f 1 un 1 cubic centimetre of the bacillary ef course, this is not so, because 1 cubic centimetre of the bacillary emulsion, for example, weighs $1 \cdot 114$ grammes, and this difference will bave to be allowed for in each individual dose of dilution if it were ordered by weight. This introduces an unnecessary factor and an altogether needless amount of trouble. So far from simplifying matters preseribing "by weight would be in troducing complications. When prescribing tuberculin by measure (in cubic centimetres) it aiminishes any possibility of a misunderstand ing as to whether the figures relate to the linpid itself or to the solid substance it contains. It is, for instance, a simple matter to recollect that 1 cubic centimetre of emulsion represents 5 milligrammes of solid matter, but not so easy to recollect that 1.114 grammes of the liquid is equivalent to the 5 milligrammes. The fact that the emulsion is standardised to 1 cubic centimetre indicates that it is intended to be prescribed "by measure" and not "by weight." It is also much more conrenient to work a fluld "by measure" than "by weight."

P. W. S@UIRE.

\section{THE VALUE OF THE ALBUMIN RE-}

\section{ACTION IN TUBERCULOUS SPUTUM.}

\section{To the Editor of THE LANCET.}

SIR, - The recent announcement of Lesieur and Prirey ${ }^{1}$ as to the presence of albumin in tuberculous sputum seemed to afford a valuable and simple aid to the diagnosis of phthisis. Being temporarily in charge of the Birmingham Municipal Sanatorium at Yardley-road at the time of the article in THE LANCET ${ }^{2}$ I took advantage of the opportunity to test the value of the reaction. The author's technique was adhered to throughout, and in the final stages nitric acid was used in preference to the heat method as being more delicate and accurate.

I was able to examine the sputum of 55 patients, of whom 39 had tubercle bacilli present and so were definitely tuberculous. Of these 39 albumin was present in 21 , or 53.8 per cent., and absent in 18 , or 46.2 per cent., so that the test appears to have no diagnostic value. No very extended conclusions can be drawn from such a small number of cases, but there appears to be a greater likelihood of the reaction being given if tubercle bacilli are present in the sputum, for of the remaining 16 cases which did not present tubercle bacilli, yet wbich otherwise showed all the signs of phthisis, and were, I think, undoubtedly tuberculous, only 4 gave the albumin reaction and 12 were negative.

I am indebted to my friend, Dr. W. H. Wynn, the visiting physician, not only for permission to publish this, but also for

1 Paris Médical, 29, vol ir 1911.

THE LAYCE'T, Oct. 14th, 19ii, p. 1084. the interest he took in the matter, and to Miss D. Dawson for ber assistance in the laboratory.

I am, Sir, yours faithfully,

H. S. Getrings, L.R.C.P. \& S. Edin.

J,F.P.S. Glasg., D P.H. Birm.,

Dec. 1st, 1911. Assistant Merical Officer. Portsmonth Municipal Tuberculin Dispensary.

\section{A SPHYGMOGRAPHIC METHOD FOR THE ESTIMATION OF SYSTOLIC AND DIASTOLIC BLOOD PRESSURE. \\ To the Editor of THE LANCET.}

SIR,-Mr. S. G. Longworth correctly remarks that in current descriptions of the Korotkoff method for the determination of the diastolic blood pressure this is read off "at the point at which a distinct change in the intensity of the sound occurs." This alteration in intensity, pitch, and duration of the sound may be phonetically represented by swist to $d u p$; the sound $d u p$ gradually increases to a maximum and then dies away as the air escapes.

The maximum intensity of the sound is taken as representing the diastolic pressure, but it is not always easy to determine this point, and different observers when examining the same patient frequently give different results, and, moreover, the sound not seldom continues equally loud over considerable differences in pressure.

I take the disappearance of the sound as the standand because the event can be certainly and readily determined, and thus has value for comparative observations on the same case. The reading so obtained is perhaps lower than the true diastolic pressure, but the difference would appear to be small. "Miss Allen and Mr. Engle, in the study of the blood pressures of 35 patients in the Johns Hopkins Hospital, found that the readings by the Korotkoff method never differed more than $2-5 \mathrm{~mm}$. from control determinations made at the same time with the Erlanger apparatus, though they took the minimal pressure at the point at which the second sound absolutely disappeared." 3

I am, Sir, yours faithfully,

Southall, W., Dec. 4th, $1911 . \quad$ J. DAYENPORT WINDLE.

\section{SUTURE OF THE ABDOMINAL WALL WITHOUT BURIED SUTURES.}

\section{To the Editor of THE LANCET.}

SIR,--In A pril, 1906, I described in THE LANCET ${ }^{2}$ a doubleloop suture which I have reason to believe has proved useful. Recently I have experimented with another form of suture which fulfils similar conditions and possibly has some advantages. The double-loop suture bad been used by several surgeons before my description of it, and this may be the case with regard to the method I wish to describe.

The advantage of the new method is that, having a single loop, it is more easily removed, and also that it draws the deep parts together with more lateral strain, thus approximating to the action of a buried suture.

A curved needle armed with silkworm gut is passed from without at some distance from the edge of the incision and through a layer of deep tissues on the opposite side; it is then repassed through the skin somewhat in front of the first puncture. The same process is repeated from the other side, the loops being interlocked. They may be tied independently, or one end may be left long and tied to the corresponding long end of the other loop.

These sutures act as " tension sutures," and a continuous horsehair is all that is required to complete the union. In removing the sutures it is best to cut both sides, otherwise the interlocking makes removal more difficult.

I am, Sir, yours faithfully

$$
\text { J. B. PIKE, M.R.O.S. Eng,, }
$$

Loughborough. Honorary Surgeon to the Loughborough Hospital.

1 Hirschfelder: Diseases of the Heart and Aorta. The LanceT, April 7th, 1906, p. 967.

Municipal Honours.-Mr. R. J. Ryle, M.D. Oxon., M.R.C.S. Eng., J.P., was on Nov. 22ud elected a member of the Brighton town conncil by a majority of 190 votes over his opponent. 